\title{
The Characteristics and Source Analysis of Heavy Metals in the Sediment of Water Area of Urban Scenic: A Case Study of the Delta Park in Suzhou City, Anhui Province, China
}

\author{
Yaqi Jiang ${ }^{1,2}$, Herong Gui ${ }^{1,2 *}$, Chen Chen ${ }^{1,2}$, Chunlei Wang ${ }^{1,2}$, Yaru Zhang ${ }^{2}$, \\ Yiheng Huang ${ }^{2}$, Hao Yu ${ }^{1,2}$, Meichen Wang, ${ }^{1,2}$, Hongxia Fang ${ }^{1,2}$, Huili Qiu ${ }^{2}$ \\ ${ }^{1}$ School of Earth and Environment, Anhui University of Science and Technology, Huainan 232001, China \\ ${ }^{2}$ National Engineering Research Center of Coal Mine Water Hazard Controlling (Suzhou University), \\ Suzhou 234000, China
}

Received: 20 July 2020

Accepted: 5 September 2020

\begin{abstract}
In order to master the environmental geochemical characteristics of heavy metals in the sediment of urban scenic areas, in this study the water area of the delta Park in Suzhou City (Anhui Province, China) as an example, the contents of $\mathrm{Pb}, \mathrm{U}, \mathrm{V}, \mathrm{Mn}, \mathrm{Ni}, \mathrm{Cr}, \mathrm{Cu}$ and $\mathrm{Zn}$ in sediment were tested. On this basis, using the Kriging spatial interpolation, self-organizing map (SOM) and positive matrix factorization model (PMF) to explore the spatial distribution, pollution characteristics and sources of heavy metals in the study area. The results showed that the heavy metal content of the sampling points in the estuary area was higher than that in the park; the potential ecological risk index and the geoaccumulation index evaluation results showed that the sediment of water area of the delta park was in a light pollution state; three pollution factors, including agricultural, industrial and natural sources, were analyzed by the positive matrix factorizing model, with contribution rates of $42.13 \%, 35.39 \%$ and $22.48 \%$ respectively, of which agricultural and industrial sources were the main sources of heavy metals in the sediments of the study area.
\end{abstract}

Keywords: heavy metal, self-organizing map, positive matrix factorization model, identification of sources

*e-mail: guiherong@163.com 


\section{Introduction}

With the rapid development of urbanization and industrialization, heavy metal pollution in sediments of rivers, lakes and other waters has become a global problem, and has been widely concerned because of the characteristics of heavy metals, such as enrichment, concealment, persistence and toxicity [1]. Sediment is an important part of aquatic ecosystem, which is not only the material basis for the growth of benthos and aquatic plants [2], but also the source of heavy metals and other pollutants. When the environmental conditions (oxidation-reduction potential, $\mathrm{pH}$, human disturbance and so on) change, heavy metals may be released from the sediment to the overlying water body, causing secondary pollution, thus affecting the water environment quality [3]. The content characteristics of heavy metals in sediment can reflect the long-term impact of human activities on the basin environment [4]. Therefore, it is of great significance to study the content, distribution characteristics and sources of heavy metals in the sediment of water area for the protection of water environment.

In recent years, many scholars have carried out a lot of research on heavy metal pollution in sediment of water area. $\mathrm{Xu}$ et al. [3] explored the distribution characteristics, influencing factors, sources, ecological hazards and geochemical baseline concentrations of $\mathrm{Sb}$ in the area of Three Gorges Reservoir, it has laid a solid foundation for the research of $\mathrm{Sb}$ in the Three Gorges reservoir. Dai et al. [5] analyzed the sources of heavy metals in the sediment of Poyang Lake, results showed that chromium, lead and zinc were mainly affected by geological processes and human activities, while copper and cadmium may be derived from agricultural non-point source pollution. Ustaoglu et al. [6] studied potentially toxic elements $(\mathrm{Al}, \mathrm{Cr}, \mathrm{Mn}, \mathrm{Fe}, \mathrm{Co}, \mathrm{Ni}, \mathrm{Cu}$, $\mathrm{Zn}, \mathrm{As}, \mathrm{Cd}, \mathrm{Pb}$ and $\mathrm{U}$ ) in the sediment of seven major rivers in the region of Gresun, Northeast Turkey, found that the quality of sediment was mainly affected by human activities. At present, there are many studies on the environmental impact of heavy metals in the sediment of water area, such as large lakes and rivers, but there are few reports on the content characteristics and source analysis of heavy metals in the sediment of urban scenic areas. From the perspective of hydrodynamic conditions, the water area of urban scenic usually has the dual attributes of dynamic rivers and still water lakes, and the environmental geochemical behavior of heavy metals in sediment is different from that of rivers and lakes. Therefore, this paper took the sediment of water area of the delta Park in Suzhou City, Anhui Province, China as the research object, discussed the distribution and source of heavy metals in the sediment, and evaluated the pollution level, so as to provide scientific basis for the assessment and management of the water environment quality of the urban scenic areas.

\section{Study Area}

Suzhou city is located in the north of Anhui Province, with a population of 6.5 million and an area of $9787 \mathrm{~km}^{2}$. This area has a warm temperate semi humid climate with four distinct seasons, windy and cold in winter, hot and rainy in summer. The annual average temperature is $14 \sim 14.6^{\circ} \mathrm{C}$, the historical highest temperature is $40^{\circ} \mathrm{C}$, and the lowest temperature is $-12.5^{\circ} \mathrm{C}$. The annual rainfall is $774 \sim 855 \mathrm{~mm}$, and the annual evaporation is $832.4 \mathrm{~mm}$. Among them, the precipitation between June and September accounts for $50 \%$ of the whole year. Suzhou Delta Park is located between Bian River and Tuo River, with a triangular shape in plan (Fig. 1), covering an area of 2,300 acres. The delta Park adopts the international advanced landscape planning and design concept, integrating ecology, nature and culture, with leisure and tourism functions. In order to ensure the tourists' sightseeing experience of water yachts and cruises, river dams are set up in the lower reaches of Bian River and Tuo River. Through water level regulation, the water surface and depth of the delta park water area are not affected by the seasons. Therefore, the water area of delta Park in the dry season has the characteristics of rivers, mainly dynamic water environment, while in the dry season it has the characteristics of lakes, mainly static water environment.

\section{Materials and Methods}

\section{Sampling and Testing}

In July 2019, a total of 15 samples of surface sediment were collected by a Peterson dredger. The samples were packed in polyethylene bags and sealed back to the laboratory. After freeze-drying, they were ground with agate mortar and screened through 100 meshes. And then after screening, the samples were sealed in brown glass bottles and refrigerated for later use. Accurately weighed about $0.2500 \mathrm{~g}$ of the sample and put it into the polytetrafluoroethylene digestion tube, add $1 \mathrm{ml}$ of hydrochloric acid, $1 \mathrm{ml}$ of nitric acid and $2 \mathrm{ml}$ of hydrofluoric acid, shaken it evenly into a $120^{\circ} \mathrm{C}$ constant temperature graphite digestion furnace, digested for about 1-2 hours, took it off and cooled it slightly, fixed the volume to $50 \mathrm{ml}$ with deionized water, shaken it well, centrifugated it for $5 \mathrm{~min} / 6000 \mathrm{rpm}$, and then shaken gently to be tested. The concentrations of $\mathrm{Pb}, \mathrm{U}, \mathrm{V}, \mathrm{Mn}, \mathrm{Ni}, \mathrm{Cr}, \mathrm{Cu}$ and $\mathrm{Zn}$ in the sediments were determined using HR-ICP-MS (Thermo Element 2, New York, USA) whose major specifications include Sensitivity $\left(>1 \times 10 \mathrm{e}^{9}\right.$ counts per second (cps)/ppm), Detection Power $(<1 \mathrm{ppq}$ for non-interfered nuclides) and Dynamic Range $\left(>10 \mathrm{e}^{9}\right.$ linear with automatic gain calibration). In order to ensure the accuracy of test results, a blank sample and sediment reference material (GSD-10(GBW 07312)) were set for each 7 samples, 


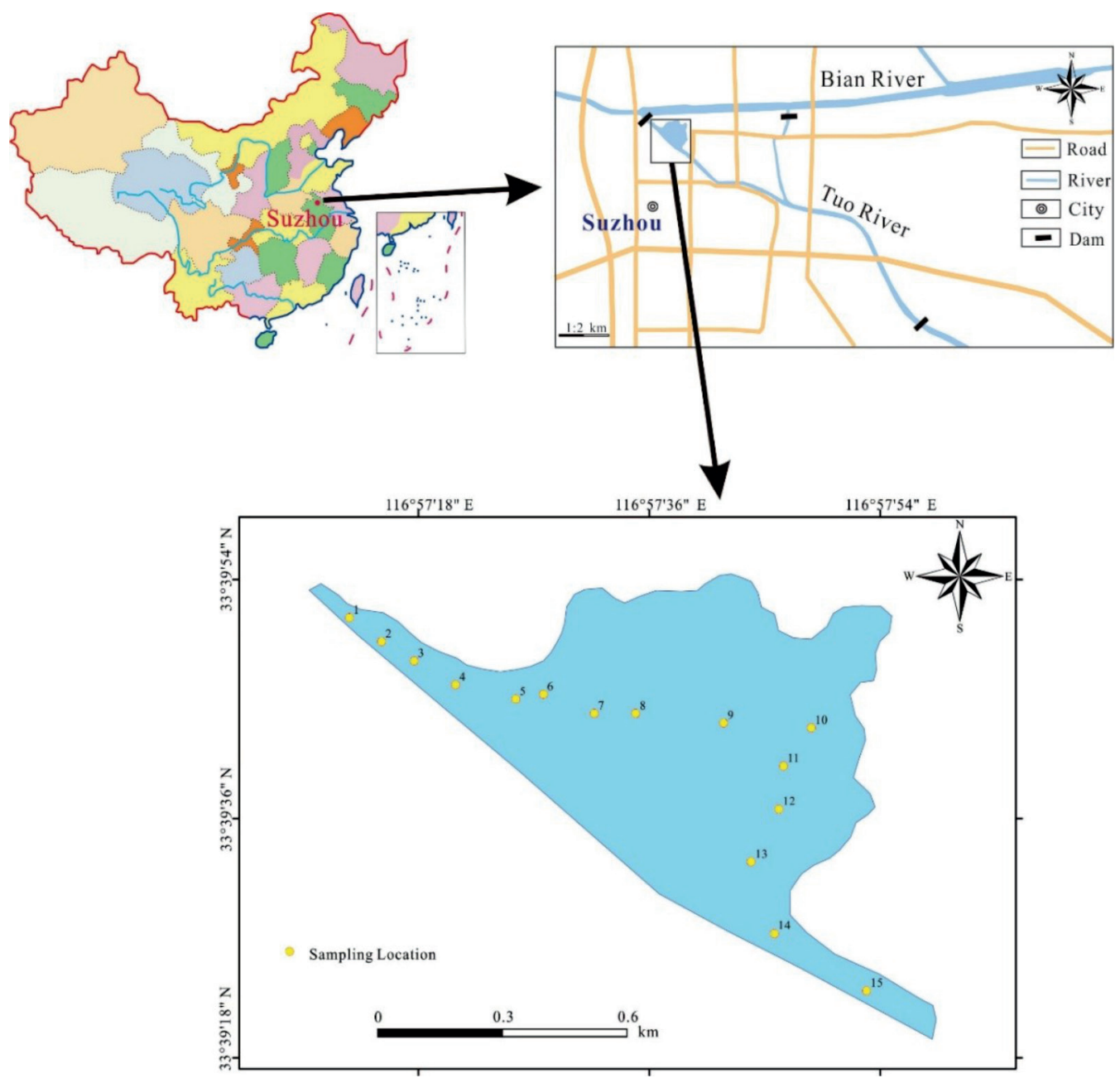

Fig. 1. Location of study area and distribution of sampling points.

and parallel samples were set at the same time. The recovery rate of the standard samples was controlled between $97 \%-105 \%$, and the relative deviation between the parallel samples was less than $5 \%$.

\section{Analysis of Self-Organizing Map}

Kohonen's self-organizing map is an unsupervised artificial neural network model that can project multidimensional data onto low-dimensional data maps. As a result, SOM compresses the original information, but keeps the most important topological relationship of the original data at the same time [7]. So it can be regarded as an abstract measure. Meanwhile, the self-organizing map has a better visualization effect.

The calculation process of SOM is as follows: firstly, a data matrix of $15 \times 8$ is generated, in which 15 is the number of samples and 8 is the number of measurement parameters ( $\mathrm{Pb}, \mathrm{U}, \mathrm{V}, \mathrm{Mn}, \mathrm{Ni}, \mathrm{Cr}, \mathrm{Cu}, \mathrm{Zn})$; the second step is to calculate the output number of neurons according to the empirical formula $M=5 N^{0.5}$ (where $M$ is the number of output neurons and $N$ is the number of samples), and combined with the model error to finally determine a $4 \times 5$ neuron matrix.
Based on Matlab 2014b software, SOM toolbox was used to complete the construction of SOM model and cluster SOM-K average value.

\section{Potential Ecological Risk Assessment}

The potential ecological risk index method (RI) is used to evaluate the potential ecological harm of heavy metals to the ecological environment by comprehensively considering the toxicity of heavy metals and the sensitivity of the environment to heavy metals [8]. The calculation formula is as follows:

$$
\begin{gathered}
E_{r}^{i}=T_{r}^{i} \times\left(C^{i} / B^{i}\right) \\
R I=\sum E_{r}^{i}
\end{gathered}
$$

...where, $C^{i}$ is the measured value of the $i$ th heavy metal; $B^{i}$ is the background value of the $i$ th heavy metal; $T_{r}^{i}$ is the Toxicity Coefficient of the $i$ th heavy metal, since there is no research on the toxicity factor of $U$ element at present, and there are few data on the abundance and release coefficient, it is impossible to calculate the toxicity factor of $\mathrm{U}$. Therefore, this article did not 
discuss the potential ecological risk of $U$ element. In this paper, the standardized toxicity coefficient of heavy metals formulated by [8] was used to determine the toxicity coefficient values of $\mathrm{Pb}, \mathrm{V}, \mathrm{Mn}, \mathrm{Ni}, \mathrm{Cr}, \mathrm{Cu}$ and Zn were 5, 2, 1, 5, 2, 5 and 1, respectively.

\section{Index of Geoaccumulation}

Muller 1969 [9] proposed the geoaccumulation index method in 1969 to evaluate the pollution degree of heavy metals in the sediment of water environment. It is one of the methods widely used to evaluate the pollution degree of heavy metals in water sediments [10]. This method can comprehensively reflect the natural changes of heavy metals and the impact of human activities on the content of heavy metals [11]. The calculation formula is as follows:

$$
I_{g e o}=\log _{2}\left[\frac{C_{i}}{\left(K \times B_{i}\right)}\right]
$$

In the formula, $C_{i}$ is the measured value of the $i$ th heavy metal; $B_{i}$ is the background value of the $i$ th heavy metal, and the heavy metal content of the soil in the Jianghuai River Basin of Anhui Province was used as the background value [12]. The value of $\mathrm{K}$ is 1.5 , which is the correction coefficient considering the change of background value caused by diagenesis and human activities [13].

\section{Positive Matrix Factorization Model (PMF)}

Positive matrix factorization model is a receptor model that can be used for quantitative source analysis [14], the principle of which is to decompose the original matrix $X_{i j}$ into two factor matrices $A_{i j}, B_{i j}$ and a residual matrix $\mathrm{e}_{i j}$ by using the least iterative square method. The calculation formula is as follows:

$$
X_{i j}=\sum_{k=1}^{p} A_{i j} B_{i j}+e_{i j}
$$

...where: $X_{i j}$ is the content of element $j$ in the $i$ th sample $(\mathrm{mg} / \mathrm{kg}) ; A_{i j}$ is the content of element $j$ in source $k ; B_{i j}$ is the contribution of source $k$ to the $i$ th soil sample; $e_{i j}$ is the residual matrix. The $e_{i j}$ formula is calculated according to the defined objective function. The objective function $Q_{i}$ is calculated as shown in Equation (5).

$$
Q=\sum_{i=1}^{n} \sum_{j=1}^{m}\left(\frac{x_{i j}-\sum_{k=1}^{p} A_{i k} B_{k j}}{u_{i j}}\right)^{2}
$$

In the formula, $u_{i j}$ is the uncertainty of the $j$ th heavy metal element in sample $i$.

The biggest advantage of PMF model is to use uncertainty to analyze the concentration data of each element in the sample respectively. It requires two input files, one is the concentration of sample species, the other is the uncertainty of sample species concentration. Use the following formula to calculate the uncertainty of concentration:

$$
\text { When } \mathrm{c} \leq \mathrm{MDL}, u_{i j}=5 /{ }_{6} \times M D L \text {; }
$$

$$
\text { When } \mathrm{c}>M D L, u_{i j}=\sqrt{(E F \times c)^{2}+(0.5 \times M D L)^{2}}
$$

...where: $\mathrm{c}$ is the concentration of elements in the sample; MDL is the detection limit of the determination method; $\mathrm{EF}$ is the precision of the determination.

\section{Results and Discussion}

\section{Statistical Analysis of Heavy Metal Content in Sediment}

The statistics of heavy metal content in sediment of Suzhou delta Park (hereinafter referred to as "delta sediment") is shown in Table 3. The average content of 8 heavy metals $\mathrm{Pb}, \mathrm{U}, \mathrm{V}, \mathrm{Mn}, \mathrm{Ni}, \mathrm{Cr}, \mathrm{Cu}$ and $\mathrm{Zn}$ was $21.45,2.39,74.23,674.90,27.71,56.41,24.56$ and $69.34 \mathrm{mg} / \mathrm{kg}$, only the average content of $\mathrm{Mn}$ and $\mathrm{Ni}$ exceeded the national stream sediment average, 1.03 and 1.21 times of the national stream sediment average, respectively. $\mathrm{Mn}$ and $\mathrm{Ni}$ generally come from the electroplating industry. Compared with the background value of soil in the Jianghuai Valley of Anhui Province, the average content of $\mathrm{U}, \mathrm{Mn}, \mathrm{Ni}$ and $\mathrm{Zn}$ in the sediment was higher, which was $1.11,1.29,1.11$ and 1.30 times of the background value, indicating that these four heavy metals are polluted to varying degrees accumulation. Coefficient of variation (CV) is a measure of the degree of data dispersion. The $\mathrm{CV}$ showed $\mathrm{Cu}>\mathrm{Zn}>\mathrm{Ni}>\mathrm{CR}$ $>\mathrm{Pb}=\mathrm{V}>\mathrm{Mn}>\mathrm{U}$, where the coefficient of variation of $\mathrm{Cu}$ was relatively large $(\mathrm{CV}>0.3)$. It indicated that the distribution of $\mathrm{Cu}$ in sediments was quite different, which may be related to factors such as water conservancy conditions and human activities [15].

Compared with the threshold effect concentration (TEC) and the possible effect concentration (PEC) in the sediment quality standard of freshwater ecosystem,

Table 1. Classification of potential ecological risk coefficient $\left(E_{r}^{i}\right)$ and ecological risk index (RI) of heavy metals $[9,10]$.

\begin{tabular}{|c|c|c|}
\hline $\begin{array}{c}\text { Potential ecological } \\
\text { risk coefficient }\left(\mathrm{E}_{\mathrm{r}}^{\mathrm{i}}\right)\end{array}$ & $\begin{array}{c}\text { Ecological risk } \\
\text { index }(\mathrm{RI})\end{array}$ & $\begin{array}{c}\text { Potential } \\
\text { ecological risk } \\
\text { degree }\end{array}$ \\
\hline$<40$ & $<150$ & Low \\
\hline $40-80$ & $150-300$ & Moderate \\
\hline $80-160$ & $300-600$ & Considerable \\
\hline $160-320$ & $\geq 600$ & High \\
\hline$\geq 320$ & - & Very high \\
\hline
\end{tabular}


Table 2. Classification of the geoaccumulation index and division of pollution level [6].

\begin{tabular}{|c|c|c|}
\hline Igeo & Grade & Sediment quality \\
\hline$\leq 0$ & 0 & Unpolluted \\
\hline $0-1$ & 1 & Unpolluted to moderately polluted \\
\hline $1-2$ & 2 & Moderately polluted \\
\hline $2-3$ & 3 & Moderately to strong polluted \\
\hline $3-4$ & 4 & Strong polluted \\
\hline $4-5$ & 5 & Strong polluted to extreme pollution \\
\hline$>5$ & 6 & Extreme pollution \\
\hline
\end{tabular}

the contents of $\mathrm{Ni}$ and $\mathrm{Cr}$ in most sampling points were between the TEC and PEC values, indicating that these two heavy metals may have lower harmful biological effects. The content of $\mathrm{Cu}$ did not exceed the TEC content at $\# 5, \# 6, \# 7, \# 8, \# 9, \# 10, \# 11$ and $\# 12$ at the center of the lake, but the sampling points near the Tuo River were higher than TEC Value. The spatial distribution of $\mathrm{Pb}, \mathrm{U}, \mathrm{V}, \mathrm{Ni}, \mathrm{Cr}, \mathrm{Cu}$ and $\mathrm{Zn}$ contents in the sediment of the Delta waters was shown in Fig. 2. It can be found that the spatial distribution characteristics of various metals were basically the same, that is, high concentration of heavy metals were mainly concentrated near the estuary, the reason may be that when the river entered the lake, the flow rate became slower and heavy metals begined to precipitate [5]. By comparing with the S9 and S10 sampling points

Table 3. Descriptive statistics of heavy metal content in sediment samples.

\begin{tabular}{|c|c|c|c|c|c|c|c|c|}
\hline Samples & $\mathrm{Pb}$ & U & V & $\mathrm{Mn}$ & $\mathrm{Ni}$ & $\mathrm{Cr}$ & $\mathrm{Cu}$ & $\mathrm{Zn}$ \\
\hline 1 & 23.22 & 2.75 & 81.25 & 688.40 & 32.58 & 63.67 & 29.23 & 76.39 \\
\hline 2 & 21.29 & 2.34 & 73.93 & 701.72 & 29.37 & 57.59 & 26.62 & 70.05 \\
\hline 3 & 23.99 & 2.46 & 74.71 & 802.40 & 28.16 & 53.97 & 25.16 & 61.75 \\
\hline 4 & 24.87 & 2.48 & 78.40 & 809.15 & 30.64 & 55.48 & 26.94 & 74.89 \\
\hline 5 & 18.34 & 2.37 & 65.31 & 599.25 & 21.64 & 46.62 & 17.06 & 49.63 \\
\hline 6 & 18.74 & 2.44 & 67.41 & 622.10 & 23.48 & 58.04 & 17.84 & 53.31 \\
\hline 7 & 20.38 & 2.25 & 77.80 & 641.45 & 29.21 & 57.64 & 24.16 & 67.30 \\
\hline 8 & 21.48 & 2.26 & 76.30 & 690.30 & 30.21 & 59.99 & 24.55 & 68.49 \\
\hline 9 & 20.71 & 2.53 & 84.32 & 746.82 & 28.79 & 62.64 & 22.56 & 68.45 \\
\hline 10 & 15.78 & 1.78 & 51.27 & 510.12 & 16.91 & 37.31 & 12.92 & 39.16 \\
\hline 11 & 16.85 & 1.87 & 51.40 & 468.73 & 16.63 & 38.34 & 13.17 & 47.76 \\
\hline 12 & 21.84 & 2.41 & 76.95 & 698.54 & 29.57 & 57.50 & 23.94 & 71.35 \\
\hline 13 & 20.25 & 2.19 & 72.79 & 642.20 & 27.05 & 54.44 & 22.92 & 67.80 \\
\hline 14 & 27.14 & 2.83 & 91.40 & 741.53 & 35.84 & 75.87 & 40.73 & 110.16 \\
\hline 15 & 26.82 & 2.90 & 90.15 & 760.72 & 35.63 & 67.09 & 40.56 & 113.62 \\
\hline Max & 27.14 & 2.90 & 91.40 & 809.19 & 35.84 & 75.87 & 40.73 & 113.62 \\
\hline Min & 15.78 & 1.78 & 51.27 & 468.73 & 16.63 & 37.31 & 12.92 & 39.16 \\
\hline Mean & 21.45 & 2.39 & 74.23 & 674.90 & 27.71 & 56.41 & 24.56 & 69.34 \\
\hline SD & 3.23 & 0.30 & 11.31 & 94.28 & 5.61 & 9.67 & 7.85 & 19.66 \\
\hline $\mathrm{CV}$ & 0.15 & 0.13 & 0.15 & 0.14 & 0.20 & 0.17 & 0.32 & 0.28 \\
\hline $\mathrm{NVSS}^{\mathrm{a}}$ & 23 & 2.4 & 77 & 653 & 23 & 54 & 20 & 67 \\
\hline $\mathrm{BV}^{\mathrm{b}}$ & 25.9 & 2.15 & 80.0 & 525.2 & 25.0 & 69.4 & 24.9 & 53.2 \\
\hline $\mathrm{TEC}^{\mathrm{c}}$ & 35.8 & - & - & - & 22.7 & 43.4 & 31.6 & 121 \\
\hline $\mathrm{PEC}^{\mathrm{d}}$ & 128 & - & - & - & 48.6 & 111 & 149 & 459 \\
\hline
\end{tabular}

$\mathrm{NVSS}^{\mathrm{a}}=$ National average value of stream sediment [16]

$\mathrm{BV}^{\mathrm{b}}=$ background value [13]

$\mathrm{TEC}^{\mathrm{c}}=$ threshold effect level [17]

$\mathrm{PEC}^{\mathrm{d}}=$ possible effect level [17] 
studied by [16] in 2011 (that is, points closer to the sampling points \#14 and \#15 in this paper), The content of heavy metals $(\mathrm{Pb}, \mathrm{Cr}, \mathrm{Cu}$, and $\mathrm{Zn})$ in the sediments of sampling points \#14 and \#15 were lower than that in
2011, which may be related to the treatment of black and smelly water body and the vegetation greening of delta ecological park in recent years.
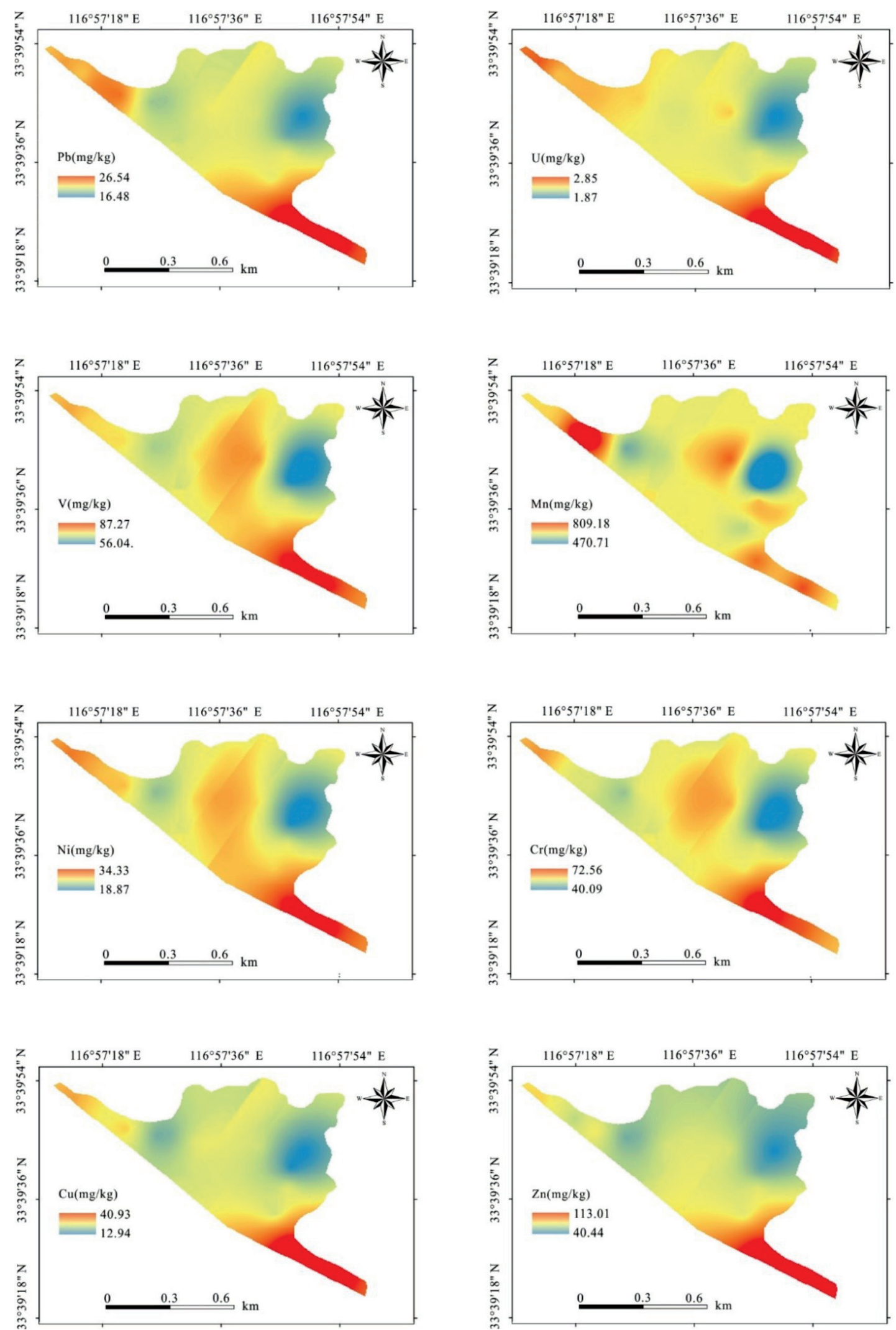

Fig. 2. Spatial distribution characteristics of 8 heavy metals in sediment of delta park waters. 

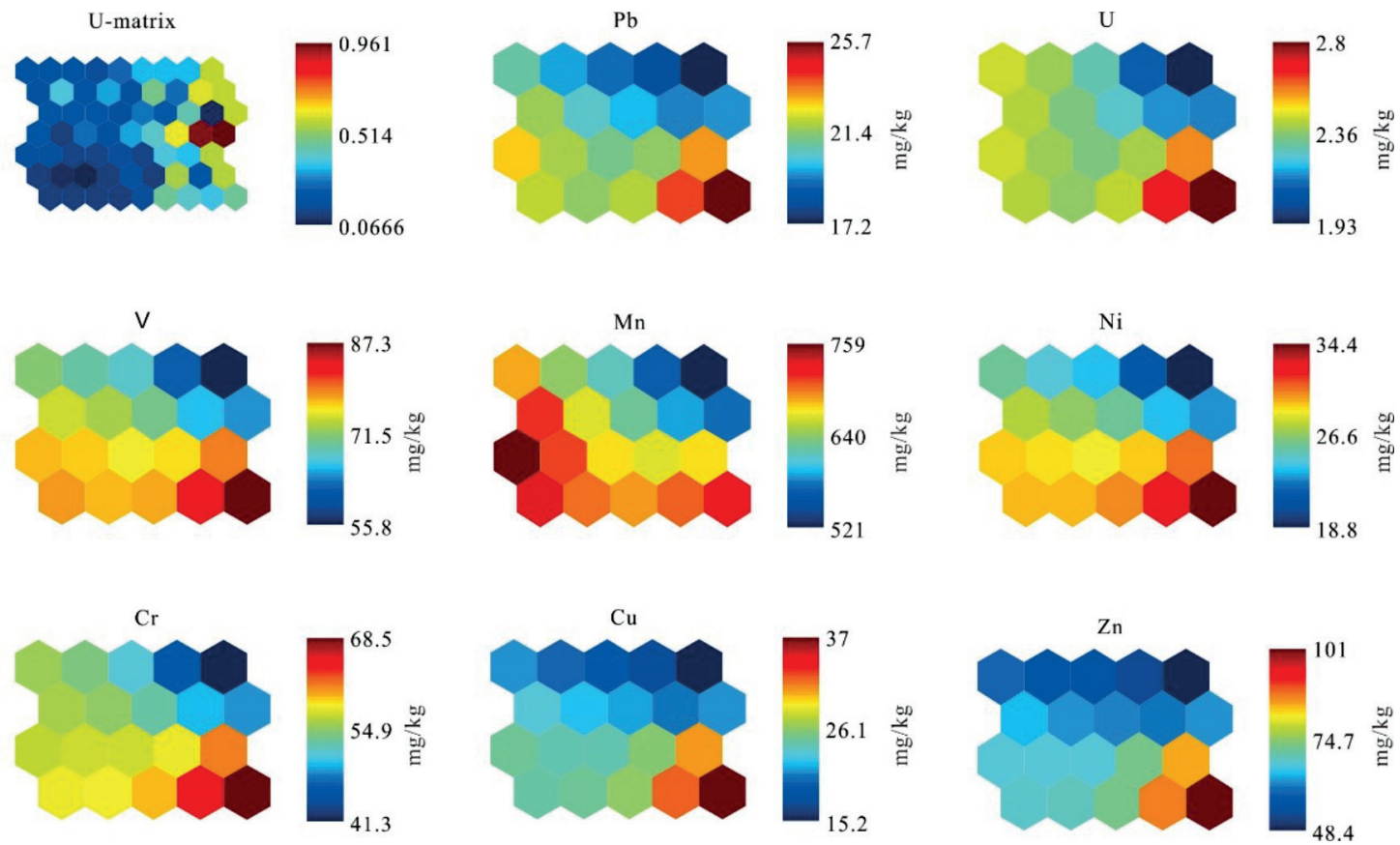

Fig. 3. SOM of heavy metals in sediment of delta Park waters.

\section{SOM Evaluation of Heavy Metals in Sediment}

Fig. 3 showed the self-organizing map of $\mathrm{Pb}, \mathrm{U}, \mathrm{V}$, $\mathrm{Mn}, \mathrm{Ni}, \mathrm{Cr}, \mathrm{Cu}$ and $\mathrm{Zn}$. Each SOM matrix presented the index value obtained after dimensionally reduction, and represented the size of the index data in blue to red. High-value neurons were expressed in red, while lowvalue neurons were expressed in blue. By comparing the color gradient changes of SOM of heavy metals, the information connection and quantitative relationship between each heavy metal can be intuitively displayed

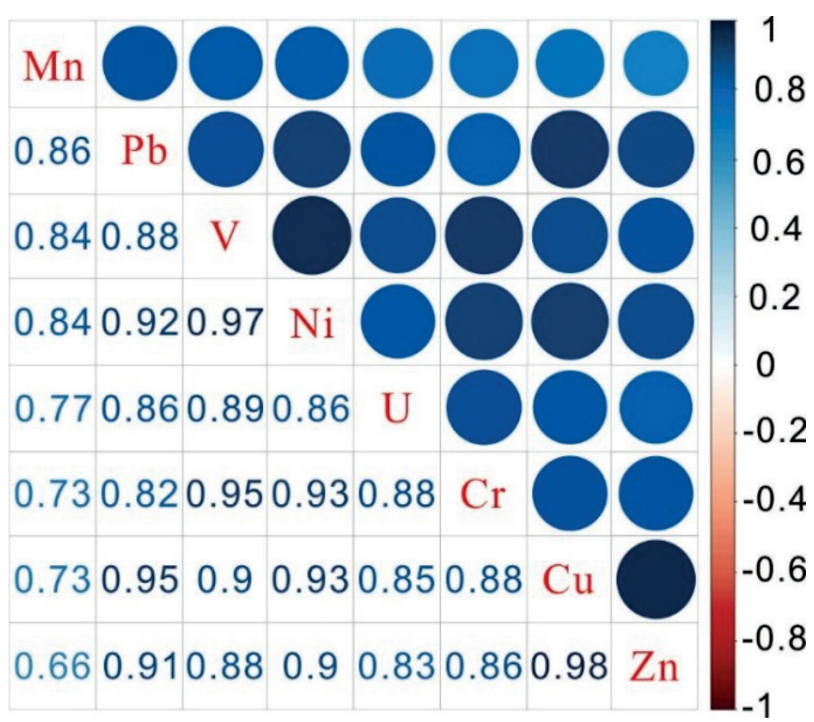

Fig. 4. Correlation analysis of heavy metals in sediment of delta Park waters.
[17]. The five heavy metals $\mathrm{Pb}, \mathrm{U}, \mathrm{V}, \mathrm{Ni}$ and $\mathrm{Cr}$ had similar color gradients, indicating a strong positive correlation between these four indexes. And there was also a strong positive correlation between $\mathrm{Cu}$ and $\mathrm{Zn}$. In order to verify the operation results of SOM, the correlation analysis results of heavy metals were shown in Fig. 4. The correlation coefficient of $\mathrm{Cu}$ and $\mathrm{Zn}$ was 0.98 , and the correlation coefficient of $\mathrm{Pb}, \mathrm{U}, \mathrm{V}, \mathrm{Ni}$ and Cr was greater than 0.8 , which showed that the internal relationship between these parameters was consistent with the qualitative relationship shown in SOM.

On the basis of SOM-K-means clustering was used to obtain Fig. 5. According to the Euclidean distance, three groups of categories were determined and represented by different colors. The first group was located in the lower right corner of Fig. 5. It can be seen that the other seven heavy metals except $\mathrm{Mn}$ in the first group (\#1 and \#14 sampling points) were relatively high.

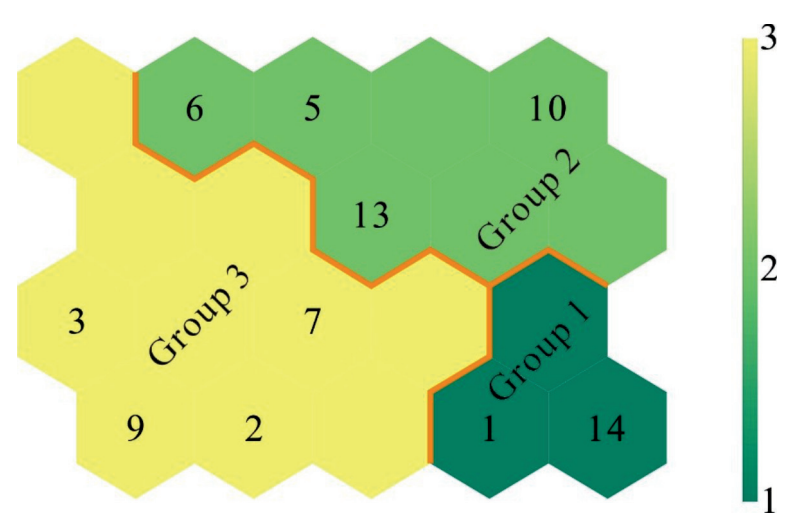

Fig. 5. SOM-K-means clustering of heavy metals in sediments of Delta Park waters. 

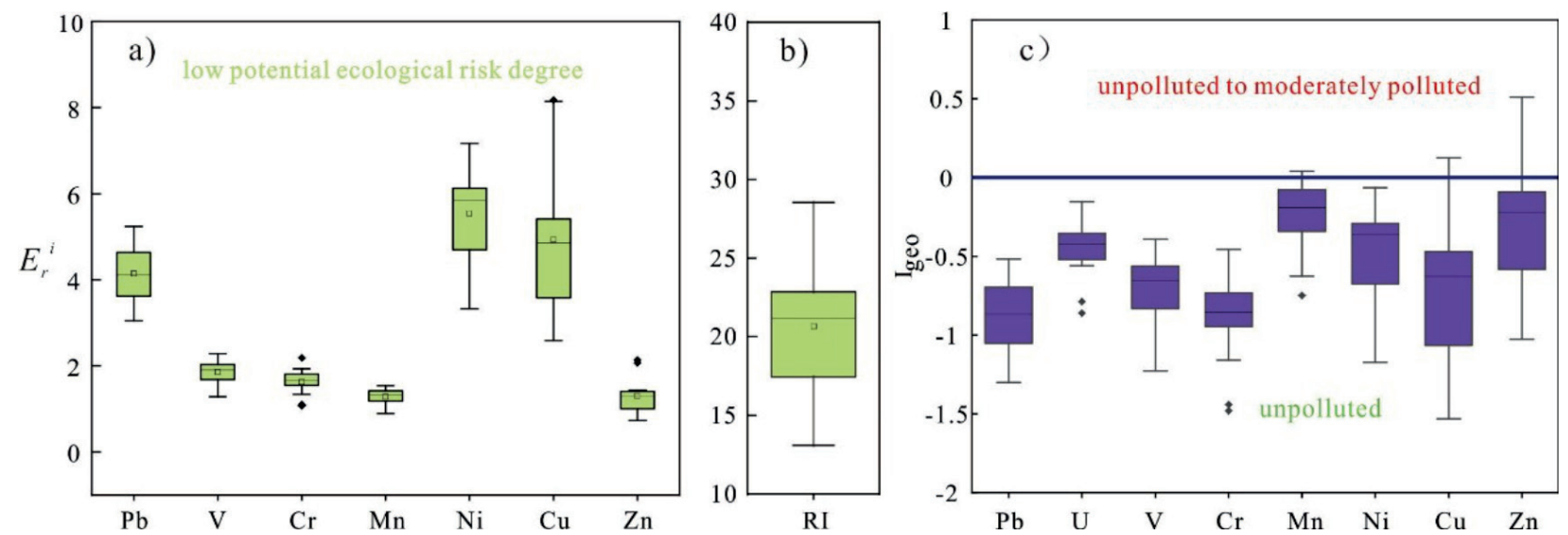

Fig. 6. Hakanson's potential ecological risk assessment box diagram and the geoaccumulation pollution index assessment box diagram.

The content of heavy metals in the second group (\#5, \#6, $\# 10$ and \#13 sampling points) in the upper right corner was lower. In the lower left corner of the third group (\#2, \#3, \#7 and \#9 sampling points) the corresponding characteristic recognition element was $\mathrm{Mn}$, that is, the content of group $3 \mathrm{Mn}$ was higher. Combined with the content distribution of various metals in Fig. 2, we can see that K-means clustering based on SOM can well reflect the spatial distribution characteristics of these eight heavy metals.

\section{Evaluation of Sediment Heavy Metal Pollution}

From Fig. 6a), it can be seen that the ecological risk coefficients of single heavy metals in the sediment of delta park were $\mathrm{Ni}, \mathrm{Cu}, \mathrm{Pb}, \mathrm{V}, \mathrm{Cr}, \mathrm{Zn}$ and $\mathrm{Mn}$ in order, and all of them were slight potential ecological risks. The potential ecological risk index (RI) was 13.09-28.54 (Fig. 6b). The seven heavy metals $\mathrm{Ni}, \mathrm{Cu}$, $\mathrm{Pb}, \mathrm{V}, \mathrm{Cr}, \mathrm{Zn}$ and $\mathrm{Mn}$ have slight potential ecological risk $(\mathrm{RI}<150)$. In order to further test the impact of human activities on the heavy metal content of the sediment in the study area, the geoaccumulation index method is used to evaluate the pollution status of

Table 4. Heavy metal pollution sources of sediment.

\begin{tabular}{|c|c|c|c|}
\hline & Factor 1 & Factor 2 & Factor 3 \\
\hline $\mathrm{Pb}$ & $37.6 \%$ & $40.7 \%$ & $21.7 \%$ \\
\hline $\mathrm{U}$ & $33.8 \%$ & $39.6 \%$ & $26.6 \%$ \\
\hline $\mathrm{V}$ & $38.5 \%$ & $33.0 \%$ & $28.5 \%$ \\
\hline $\mathrm{Cr}$ & $40.1 \%$ & $31.4 \%$ & $28.5 \%$ \\
\hline $\mathrm{Mn}$ & $34.1 \%$ & $34.1 \%$ & $31.8 \%$ \\
\hline $\mathrm{Ni}$ & $44.8 \%$ & $29.5 \%$ & $25.7 \%$ \\
\hline $\mathrm{Cu}$ & $56.2 \%$ & $35.0 \%$ & $8.8 \%$ \\
\hline $\mathrm{Zn}$ & $51.9 \%$ & $39.8 \%$ & $8.2 \%$ \\
\hline
\end{tabular}

the sediment. The evaluation results were shown in Fig. 6c): the cumulative index of $\mathrm{Pb}, \mathrm{U}, \mathrm{V}, \mathrm{Cr}$ and $\mathrm{Ni}$ in the sediment samples was less than 0 , which belonged to the non-pollution state. The geoaccumulation index of $\mathrm{Mn}$ in samples \#3 and \#4 was between 0 and 1, while those of $\mathrm{Cu}$ and $\mathrm{Zn}$ with a small number of samples (\#14 and \#15) were between 0 and 1, and these samples $(\# 3, \# 4, \# 14, \# 15)$ were located at estuary.

\section{Analysis of Heavy Metal Sources}

The main sources of heavy metals in sediments were analyzed by using positive matrix factorization model (PMF). PMF, first proposed by Paatero in 1994, is a non negative constrained source analytical equation based on the receptor model of principal component analysis [18-20]. Three main sources of heavy metals in sediment of delta Park waters were determined by PMF model. It can be seen from Table 4 that factor 1 can be regarded as agricultural source, because the contribution of $\mathrm{Cu}$ and $\mathrm{Zn}$ was very high, accounting for $56.2 \%$ and $51.9 \%$ respectively, which may be because the use of chemical fertilizer was usually related to

Agricultural activities Industrial activity

Nature factor

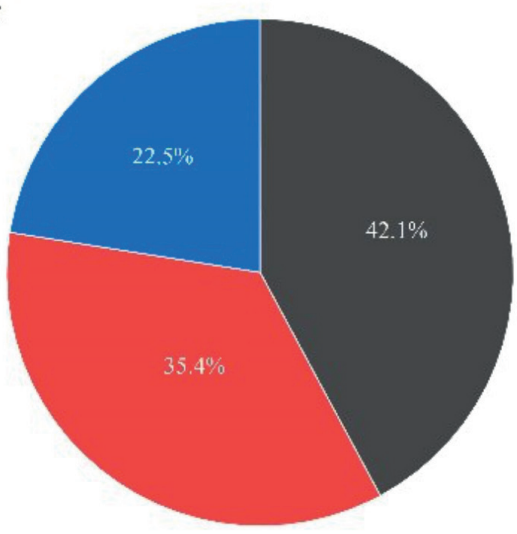

Fig. 7. Total contribution ratio of different sources. 
the enrichment of $\mathrm{Cu}$ and $\mathrm{Zn}$ in the environment [2]. Factors 2 were mainly $\mathrm{Pb}, \mathrm{U}, \mathrm{Zn}$ and $\mathrm{Cu}$, among which $\mathrm{Pb}$ contributed the most, accounting for $40.7 \%$. Suzhou is a typical resource-based city with abundant coal resources [21]. Coal combustion has been proved to increase the $\mathrm{Pb}$ concentration in sediments [22]. Therefore, factor 2 can be regarded as an industrial source. The mark elements of factor 3 were $\mathrm{Mn}, \mathrm{V}$ and $\mathrm{Cr}$, accounting for $31.8 \%, 28.5 \%$ and $28.5 \%$ respectively. Combined with the three heavy metals of $\mathrm{Mn}, \mathrm{V}$ and $\mathrm{Cr}$, the proportion of factor 1 and factor 2 was greater than factor 3, and [21] took the dust fall in the study area as the research object, indicating that the sources of $\mathrm{Fe}$ and $\mathrm{Mn}$ in the dust fall were natural causes. In view of the content of $\mathrm{Cr}$ and $\mathrm{V}$ was lower than the background value, factor 3 can be regarded as natural sources.

According to the average value of the contribution percentage of three factors of heavy metal sources to the sediment, it is taken as the contribution percentage of each source to the sediment. As shown in Fig. 7, agricultural source, industrial source and natural source accounted for $42.1 \%, 35.4 \%$ and $22.5 \%$ respectively. If the agricultural source and industrial source were attributed to the influence of human activities, we can see that the influence of human activities accounted for $76.5 \%$.

\section{Conclusions}

(1) The analysis of heavy metal content showed that the average content of $\mathrm{U}, \mathrm{Mn}, \mathrm{Ni}$ and $\mathrm{Zn}$ was 1.11, $1.29,1.11$ and 1.30 times of the background value, respectively. The spatial distribution characteristics of heavy metal content were basically the same: that is, the samples located in the estuarine area had higher heavy metal content. Through SOM analysis, we can found that SOM and SOM-K-means clustering can well reveal the internal relationship and distribution characteristics of heavy metals in the sediment of water area of the delta park.

(2) The results of potential ecological evaluation showed that seven heavy metals, $\mathrm{Ni}, \mathrm{Cu}, \mathrm{Pb}, \mathrm{V}, \mathrm{Cr}, \mathrm{Zn}$ and $\mathrm{Mn}$, had slight potential ecological risks. The results of the geoaccumulation index method showed that $\mathrm{Pb}$, $\mathrm{U}, \mathrm{V}, \mathrm{Cr}$ and $\mathrm{Ni}$ were in the state of no pollution, and the geoaccumulation index of $\mathrm{Mn}$ at points \#3 and \#4 and $\mathrm{Cu}$ and $\mathrm{Zn}$ at points $\# 14$ and $\# 15$ were between 0 and 1 , indicating that there was a slight enrichment of $\mathrm{Mn}, \mathrm{Cu}$ and $\mathrm{Ni}$ in the estuary area.

(3) According to the PMF source analysis model, three factors, namely factor 1 (agricultural industry source), factor 2 (industrial source) and factor 3 (natural source), accounted for $42.13 \%, 35.39 \%$ and $22.48 \%$ respectively, with agricultural and industrial sources as the main sources, and the influence of human activities accounted for $76.5 \%$.

\section{Acknowledgements}

This research was funded by the National Natural Science Foundation of China (41773100 and 41373095), the postgraduate innovation fund project of Anhui university of science and technology (2019CX2006), the Research Project of Huaibei Mining Group Co. (2020), and the Research Project of Wanbei CoalElectricity Group Co. Ltd (2020), Anhui Natural Science Foundation of China (2008085QD192).

\section{Conflict of Interest}

The authors declare no conflict of interest.

\section{References}

1. LI C., SONG C., YIN Y., SUN M., TAO P., SHAO M. Spatial distribution and risk assessment of heavy metals in sediments of Shuangtaizi estuary, China. Marine Pollution Bulletin 98 (1-2), 358, 2015.

2. LI Y.Y., GAO B., XU D.Y., PENG W.Q., LIU X.B., QU X.D., ZHANG M. Hydrodynamic impact on trace metals in sediments in the cascade reservoirs, North China. Science of the Total Environment 716, 9, 2020.

3. XU D.Y., GAO B., PENG W.Q., GAO L., LI Y.Y. Geochemical and health risk assessments of antimony (Sb) in sediments of the Three Gorges Reservoir in China. Science of the Total Environment 660, 1433, 2019.

4. WIJESIRI B., LIU A., DEILAMI K., HE B., HONG N., YANG B., ZHAO X., AYOKO G., GOONETILLEKE A. Nutrients and metals interactions between water and sediment phases: An urban river case study. Environmental Pollution 251, 354, 2019.

5. DAI L.J., WANG L.Q., LI L.F., LIANG T., ZHANG Y.Y., MA C.X., XING B.S. Multivariate geostatistical analysis and source identification of heavy metals in the sediment of Poyang Lake in China. Science of the Total Environment 621, 1433, 2018

6. USTAOGLU F., ISLAM M.S. Potential toxic elements in sediment of some rivers at Giresun, Northeast Turkey: A preliminary assessment for ecotoxicological status and health risk. Ecological Indicators 113, 106237, 2020.

7. NGUYEN T.T., KAWAMURA A., TONG T.N., AMAGUCHI H., NAKAGAWA N., GILBUENA R., BUI D.D. Identification of spatio-seasonal hydrogeochemical characteristics of the unconfined groundwater in the Red River Delta, Vietnam. Applied Geochemistry 63, 10, 2015.

8. HAKANSON L. An ecological risk index for aquatic pollution control.a sedimentological approach. Water Research 14 (8), 975, 1980.

9. MULLER G. Index of Geoaccumulation in Sediments of the Rhine River. Geojournal 2 (3), 109, 1969.

10. SOLGI E., ESMAILI-SARI A., RIYAHI-BAKHTIARI A., HADIPOUR M. Soil Contamination of Metals in the Three Industrial Estates, Arak, Iran. Bulletin of Environmental Contamination and Toxicology 88 (4), 634, 2012.

11. HUANG D.W., GUI H.R. Distribution features and internal relations of heavy metals in soil-maize system of 
mining area, Anhui Province, Eastern China. Human and Ecological Risk Assessment 25 (4), 863, 2019.

12. CHEN X.R., CHEN F.G., S.J., J., CHEN Y.N. Soil geochemical baseline and background in Yangtze River Huaihe River basin of Anhui Province. Geology in china 39 (02), 302-, 2012.

13. MAANAN M., SADDIK M., MAANAN M., CHAIBI M., ASSOBHEI O., ZOURARAH B. Environmental and ecological risk assessment of heavy metals in sediments of Nador lagoon, Morocco. Ecological Indicators 48, 616, 2015.

14. ESMAEILIRAD S., LAI A., ABBASZADE G., SCHNELLE-KREIS J., ZIMMERMANN R., UZU G., DAELLENBACH K., CANONACO F., HASSANKHANY H., ARHAMI M., et al. Source apportionment of fine particulate matter in a Middle Eastern Metropolis, TehranIran, using PMF with organic and inorganic markers. Science of the Total Environment 705, 16, 2020.

15. YANG S., QU Y., MA J., LIU L., WU H., LIU Q., GONG Y., CHEN Y., WU Y. Comparison of the concentrations, sources, and distributions of heavy metal(loid)s in agricultural soils of two provinces in the Yangtze River Delta, China. Environ Pollut 264, 114688, 2020.

16. CHEN S., HUANG S.L., SUN L.H., ZHANG Y. Geochemical Characteristics of Heavy Elements in Sediments of the Tuohe River in Suzhou City, Anhui Province. Earth and Environment 39 (03), 331, 2011.
17. ZHU G., WU X., GE J., LIU F., ZHAO W., WU C. Influence of mining activities on groundwater hydrochemistry and heavy metal migration using a selforganizing map (SOM). Journal of Cleaner Production 257 (2020), 120664, 2020.

18. PAATERO P., TAPPER U. Positive Matrix Factorization: A Non-Negative Factor Model with Optimal Utilization of Error Estimates of Data Values. Environmetrics 5 (2), 111, 1994.

19. PATERSON K. Analysis of Air Quality Data Using Positive Matrix Factorization. Environmental Science Technology 33 (4), 635, 1999.

20. LI J., SONG L.T., CHEN H.Y., WU J., TENG Y.G. Source apportionment of potential ecological risk posed by trace metals in the sediment of the Le'an River, China. Journal of Soils and Sediments 20 (5), 2460, 2020.

21. LIN M.L., GUI H.R., WANG Y., PENG W.H. Pollution characteristics, source apportionment, and health risk of heavy metals in street dust of Suzhou, China. Environmental Science and Pollution Research 24 (2), 1987, 2017.

22. LV J.S. Multivariate receptor models and robust geostatistics to estimate source apportionment of heavy metals in soils. Environmental Pollution 244, 72, 2019. 